\title{
Variation in the yield point of differentially quenched rails at severe plastic deformation
}

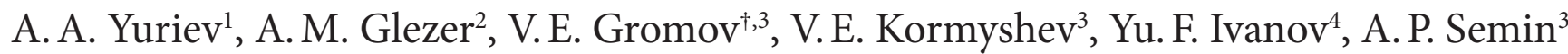 \\ †gromov@physics.sibsiu.ru \\ ${ }^{1}$ JSC “Evraz-integrated West-Siberian Metallurgical works”, Novokuznetsk, 654043, Russia \\ ${ }^{2}$ G. V. Kurdyumov Institute of Metal Science and Physics of Metals, I. P. Bardin Central Research Institute of Ferrous \\ Metallurgy, Moscow, 105005, Russia \\ ${ }^{3}$ Siberian State Industrial University, Novokuznetsk, 654007, Russia \\ ${ }^{4}$ Institute of High Current Electronics SB RAS, Tomsk, 634055, Russia
}

Regularities and mechanisms of the formation of structural-phase states and properties at different depths in the railheads along the central axis and fillet after differential quenching of 100-meter rails and extremely long operation (passed tonnage 1411 million tons gross weight) have been revealed by the methods of the modern material science. It has been shown that differential quenching is accompanied by the formation of a morphologically multi-aspect structure presented by grains of lamellar perlite, ferrite-carbide mixture and structure-free ferrite. It has been shown that extremely long operation of rails is accompanied by numerous transformations of the metal structure of the rail head. Based on the analysis of the evolution of structural phase states along different directions in the head of 100-meter differentially quenched rails after a passed tonnage of 1411 million tons and an estimation of the contributions into the strengthening of surface layers, the dependence of the total yield point on the distance to the surface along the central axis and the symmetry axis of fillet is revealed. During long-term operation of rails, the degradation of the lamellar pearlite structure occurs in a layer with a thickness of $\approx 10 \mathrm{~mm}$. A submicron- and nano-sized subgrain structure is formed in the surface layer. It is shown that the failure of the rail metal will take place in the surface layer of fillet, where the critical level of the structure is formed.

Keywords: degradation of structure, strengthening, total yield point, rails, long-term operation.

УДК: 669.539.382:669.17:625.1

\section{Изменение предела текучести дифференцированно} закаленных рельсов при сильной пластической деформации

\author{
Юрьев А. А. ${ }^{1}$, Глезер А. М. ${ }^{2}$, Громов В.Е. ${ }^{\dagger}, 3$, Кормышев В. Е. ${ }^{3}$, \\ Иванов Ю. Ф. ${ }^{4}$, Семин А.П. ${ }^{3}$ \\ ${ }^{1} \mathrm{AO}$ «Евраз-объединенный Западно-Сибирский металлургический комбинат», Новокузнецк, 654043, Россия \\ ${ }^{2}$ Институт металловедения и физики металлов им. Г.В. Курдюмова ЦНИИчермет им. И.П. Бардина, \\ Москва, 105005, Россия \\ ${ }^{3}$ Сибирский государственный индустриальный университет, Новокузнецк, 654007, Россия \\ ${ }^{4}$ Институт сильноточной электроники СО РАН, Томск, 634055, Россия
}

Методами современного физического материаловедения выявлены закономерности и механизмы формирования структурно-фазовых состояний и свойств на различной глубине в головке рельсов по центральной оси и выкружке после дифференцированной закалки 100-метровых рельсов и экстремально длительной эксплуатации (пропущенный тоннаж 1411 млн. тонн брутто). Показано, что дифференцированная закалка сопровождается формированием морфологически многоплановой структуры, представленной зернами пластинчатого перлита, феррито-карбидной смеси и структурно-свободного феррита. Показано, что экстремально длительная эксплуатация рельсов сопровождается множественным преобразованием структуры металла головки рельсов. На основании анализа эволюции структурно-фазовых состояний по разным направлениям в головке 100-метровых дифференцированно закаленных рельсов после пропущенного тоннажа 1411 млн. тонн и оценки вкладов в упрочнение поверхностных слоев выявлена 
зависимость суммарного предела текучести от расстояния до поверхности вдоль центральной оси и оси симметрии выкружки. Длительная эксплуатация рельсов сопровождается деградацией структуры пластинчатого перлита в слое толщиной $\approx 10$ мм. В поверхностном слое формируется субмикро и нанокристаллическая субзеренная структура. Показано, что разрушение металла рельсов будет происходить в поверхностном слое выкружки, где формируется критический уровень структуры.

Ключевые слова: деградация структуры, упрочнение, суммарный предел текучести, рельсы, длительная эксплуатация.

\section{Introduction}

The processes of formation and evolution of structural phase states and properties of surface layers of rails in long-term operation represent a complex group of interrelated scientific and technical problems. The importance of information in this field is determined by the depth of understanding of the fundamental problems of the physics of condensed matter, on the one hand, and the practical importance of the problem, on the other hand $[1,2]$. Consideration of the behaviour of rails in long-term operation and analysis of the reasons for their withdrawal have recently been of great interest.

In the context of the crystal lattice curvature [3], the formation of high operation properties of rails should be based on the knowledge of the mechanisms of structural phase changes in the cross-section of rails in their longterm operation. Such mechanisms can only be revealed by analyzing the evolution regularities of fine structure parameters and estimating the contributions of structural constituents and defect substructure to the strength of rails in long-term operation $[4,5]$.

The high level of contact stresses in the rail head metal causes significant irreversible changes already with a comparatively small passed tonnage. This applies to the surface layers, where substantial changes in the structure, irregular high values of microhardness, the phenomena of cementite dissolution, etc are observed. This can be the reason for the failure of rails [6,7]. Issues related to the wear of rails have recently been surveyed in detail in foreign literature. It is proved that wear defects are initially formed in the surface layers, in this case, the onset of permanent wear coincides with the accumulation of a definite level of plastic deformation [8-13].

The goal of the research is to establish the character of the variation in the total yield point along the cross-section of rails on the basis of the estimation of the mechanisms of strengthening of the surface layers.

\section{Material and Methods}

100-meter differentially quenched rails of DT350 category withdrawn from the track on the Experimental ring of Russian Railways after a gross passed tonnage of $1411 \mathrm{mln}$. tons were used as a material under study. The chemical composition of the sample metal met the requirements of specification for E76KhF steel (C: 0.71-0.82; Si: $0.25-0.60$; $\mathrm{Mn}: 0.75-1.25 ; \mathrm{Cr}: 0.2-0.8 ; \mathrm{V}: 0.03-0.15 ; \mathrm{Fe}$ - basis metal). The structure and phase composition of the rail metal at different distances from the tread surface along the central axis and along the fillet (Fig. 1) were studied by the methods of scanning and transmission electron microscopy.

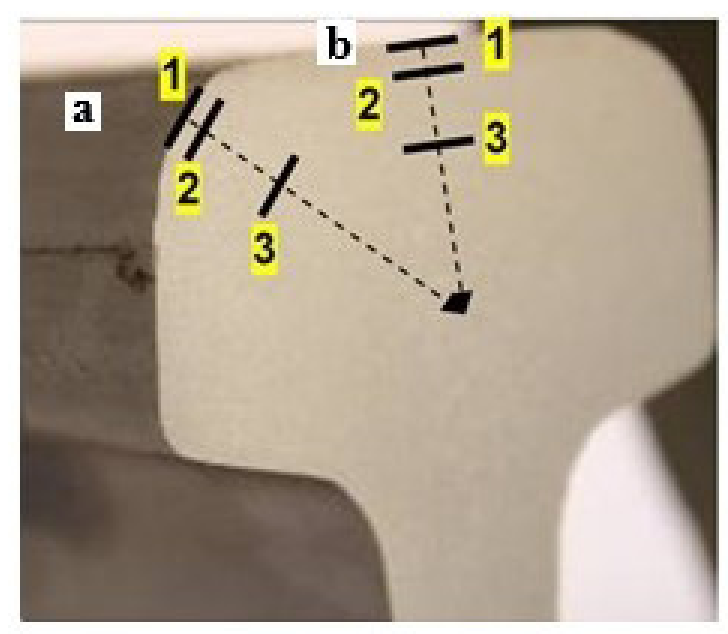

Fig. 1. Diagram of sample preparation in making subjects of research by methods of transmission electron microscopy. 1 - tread surface, 2 - layer at a distance of $2 \mathrm{~mm}$ from the surface, 3 - layer at a distance of $10 \mathrm{~mm}$ from the surface; $\mathrm{a}-$ fillet; $\mathrm{b}-$ central axis.

\section{Results and Discussion}

Differential quenching of rails results in the formation of a structure presented by pearlite grains of lamellar morphology, grains of degenerate pearlite (ferrite-carbide mixture) and grains of structure-free ferrite (ferrite grains containing no cementite particles) [2].

Long-term operation of rails leads to a substantial transformation of the structural phase state of rails. Firstly, it is a failure of the lamellar pearlite structure and the formation of a subgrain structure with submicron (100-150 nm) dimensions in the volume of pearlite colonies. Secondly, it is the precipitation of carbide phase particles of nanometer range along the boundaries and in the volume of subgrains. Thirdly, it is the increase in microdistortions and crystal lattice parameter of a solid solution based on a-iron. Fourthly, it is work hardening of metal leading to the increase (by 1.5 time) in scalar and excess dislocation density [3, 14-17] relative to the initial state.

In the layer forming the surface of the working fillet, the dimensions of subgrains (fragments) vary within the limits of 30-40 nm (Fig. 2a). In the layer forming the tread surface, the dimensions of subgrains vary within the limits of 150-300 nm (Fig. 2 b). The relative content of the subgrain structure in the surface layer of the working fillet is $25 \%$; in the surface layer of the tread surface it is $15 \%$.

The established transformations of the steel structure will influence significantly the strength and plastic characteristics 
of the metal, determining the service life of the product. Evaluation of the strengthening mechanisms allows us to reveal the regularities connecting the parameters of the structure and the strength properties of the material, and to disclose the physical nature of the process of evolution of properties. We chose the yield point as an integral criterion for changing properties, because it depends on many factors of strengthening presented in [3,15-17].

In this case, it is necessary to take into account the contributions caused by the matrix lattice friction, intraphase boundaries, dislocation substructure, the presence of carbide particles, internal stress fields, solid solution strengthening, pearlite constituent of the steel structure [4,5,14-17].

Basing on the principle of additivity, which assumes the independent action of each of the material strengthening mechanisms, to the first approximation the total yield stress can be represented as the linear sum of the contributions of separate mechanisms of strengthening:

$$
\begin{aligned}
\sigma & =\Delta \sigma_{0}+\Delta \sigma(\mathrm{L})+\Delta \sigma(\rho)+\Delta \sigma(\mathrm{h})+\Delta \sigma(\text { part. })+ \\
& +\Delta \sigma(\text { sol. sol. })+\Delta \sigma(\mathrm{P}) .
\end{aligned}
$$

$\Delta \sigma_{0}=30 \mathrm{MPa}$ is the contribution due to the matrix lattice friction, $\Delta \sigma(\mathrm{L})$ is the contribution due to intraphase boundaries, $\Delta \sigma(\rho)$ is the contribution due to the dislocation substructure, $\Delta \sigma$ (part.) is the contribution due to the presence of carbide phase particles, $\Delta \sigma(\mathrm{h})$ is the contribution due to the internal stress fields, $\Delta \sigma$ (sol.sol.) is the contribution due to the solid solution strengthening, $\Delta \sigma(\mathrm{P})$ is the contribution due to the pearlite constituent of the steel structure $[4,5,14-17]$. The numerical values of these quantities for calculating the yield point were taken from our papers [3,15-17].

Dependences of the total yield point of 100-meter differentially quenched rail steel on the distance to the rail head, shown in Fig. 3, allow us to trace the change in the yield point strength of the metal in the process of operation. It is clearly seen that only the surface layer of the rail metal not more than $2 \mathrm{~mm}$ in thickness is subjected to strengthening. With a larger distance from the rail head surface, the strength properties of steel remain at the level of those in the initial state. The strength of the steel surface layer depends substantially on the location of the layer being analyzed, namely, the strength of the surface layer of the working fillet metal is practically 2 -fold higher than that of the tread surface metal. Different values of the yield point for the tread surface and the fillet and their variation in cross-section are connected, in our opinion, with a more intensive deformation effect on fillet in operation.

Comparison with the estimation results of the steel total yield point of 100-meter differentially quenched rails with a passed tonnage of $691.8 \mathrm{mln}$. tons $[4,5]$ shows that the increase in the passed tonnage up to $1411 \mathrm{mln}$. tons leads

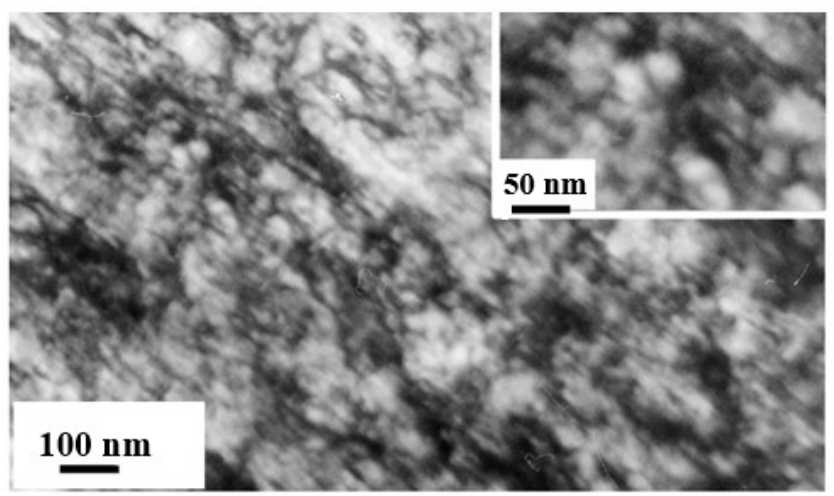

a

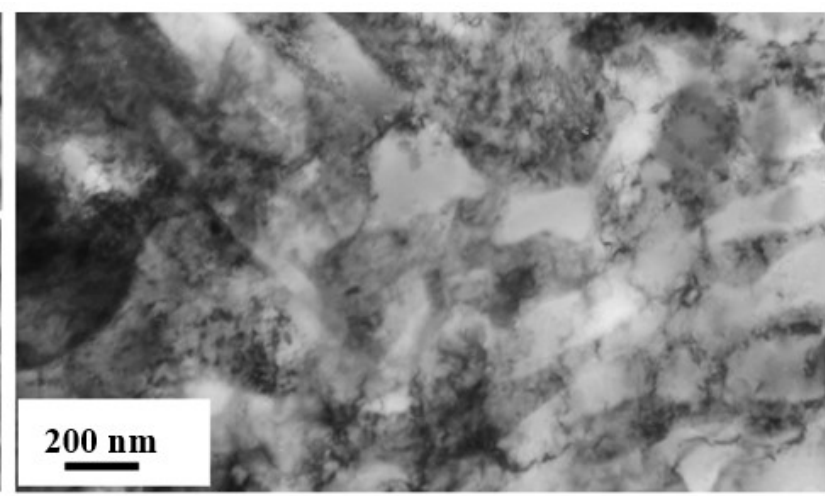

b

Fig. 2. Electron microscope images of the surface layer structure of the working fillet (a) and the tread surface (b).

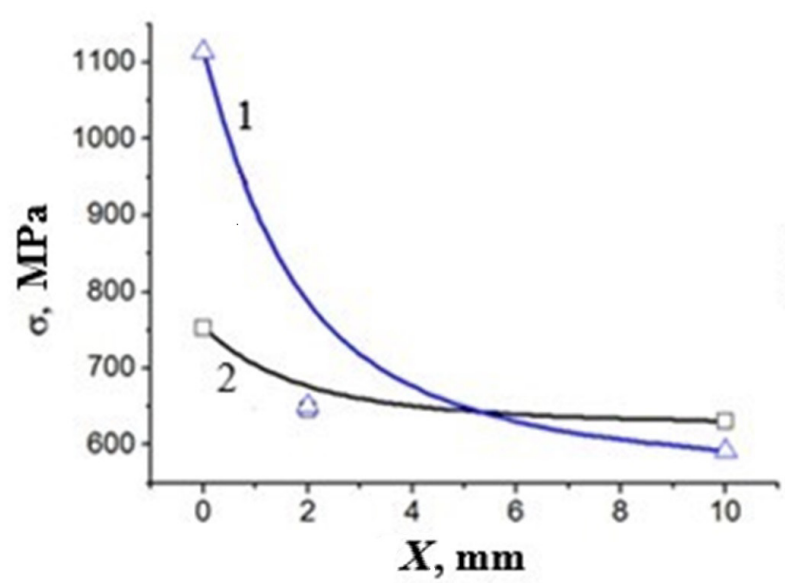

a

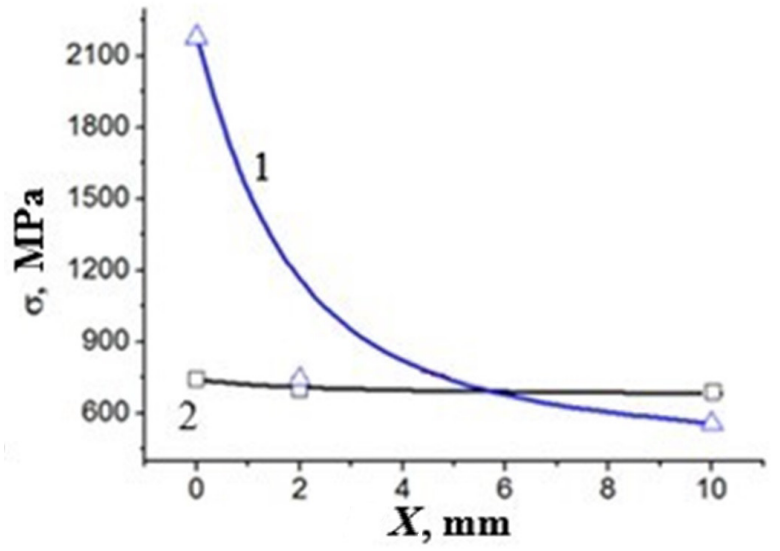

$\mathrm{b}$

Fig. 3. Dependences of the total yield point of steel on the distance to the rail head surface along the central axis (a) and along the symmetry axis of the working fillet (b); curve $1-1411 \mathrm{mln}$. tons; curve 2 - initial state. 
to a substantial increase (by $1.5-2$ times) in the yield point strength of steel.

Severe plastic deformation is accompanied by structure fragmentation and phase transformations $[18,19]$ in most metals and alloys. First of all, this manifests itself in an increase in the curvature of the crystal lattice and a decrease in translational invariance [20]. There is a change in the deformation substructure and its capacity to resist the effect of mechanical loads. The formation of a fragmented structure with subgrain sizes down to $100 \mathrm{~nm}$ in the surface layer of the working fillet precedes the development of failure processes. Nano- and microcracks develop along boundaries of such fragments in subsequently.

\section{Conclusion}

Long-term operation of rails is accompanied by structural degradation of lamellar pearlite colonies. The failure of cementite occurs in a layer with a thickness of $\approx 10 \mathrm{~mm}$. A submicro- and nanocrystalline subgrain structure is formed in surface layer of the rail head. The relative content of such a fragmentary structure amounts to $25 \%$ in surface layer of the working fillet; it is $15 \%$ in that of the tread surface. The character of the variation in the total yield point along different directions in the rail head has been established and it has been noted that the metal failure will occur in the surface layer of the fillet, where the critical level of the crystal lattice curvature is formed. Comparison with the estimation results of the total yield point with a passed tonnage of 691.8 million tons has been made.

Acknowledgements. The analysis of the steel structural phase state is supported by the RFBI grant (project № 19-32-60001), the analysis of strengthening mechanisms is funded by the RSF grant (project № 19-19-00183).

\section{References}

1. V.E. Gromov, O. A. Peregudov, Yu. F. Ivanov, S. V. Konovalov, A.A. Yuriev. Evolution of structural-phase states of rail metal in long-term operation. Novosibirsk, SB RAS (2017) 164 p. (in Russian) [В.Е. Громов, О.А. Перегудов, Ю.Ф. Иванов, С. В. Коновалов, А. А. Юрьев. Эволюция структурно-фазовых состояний металла рельсов при длительной эксплуатации. Новосибирск, Издво СО РАН (2017) 164 c.]

2. V.E. Gromov, A.B. Yuriev, K. V. Morozov, Yu. F. Ivanov. Microstructure of quenched rails. Cambridge, CISP Ltd (2016) $153 \mathrm{p}$.

3. V.E. Panin, V.E. Gromov, Yu. F. Ivanov, A.A. Yuriev, V.E. Kormyshev. Doklady Rossijskoj Akademii Nauk. Fizika, Tekhnicheskie Nauki. 494, 68 (2020). (in Russian)
[В.Е. Панин, В.Е. Громов, Ю.Ф. Гванов, А. А. Юрьев, В.Е. Кормышев. Доклады Российской Академии Наук. Физика, Технические Науки. 494, 68 (2020).] Crossref

4. Y.F. Ivanov, V.E. Gromov, A.A. Yur'ev, A.M. Glezer, N.A. Popova, O.A. Peregudov, S.V. Konovalov. Russ. Metall. 10, 985 (2018). Crossref

5. V.E. Gromov, A. M. Glezer, K. V. Morozov, Yu. F. Ivanov, K. V. Volkov. Russ. Metall. 13, 1094 (2015). Crossref

6. Yu. Ivanisenko, W. Lojkowski, H.-J. Fecht. Science Forum. 539 - 543, 4681 (2007). Crossref

7. Yu. Ivanisenko, I. Maclaren, X. Souvage, R.Z. Valiev, H. J. Fecht. Acta Mater. 54, 1659 (2006). Crossref

8. J.-W. Seo, H.-K. Jun, S.-J. Kwon, D.-H. Lee. Int. J. Fatigue. 83, 184 (2016). Crossref

9. R. Lewis, P. Christoforou, W. J. Wang, A. Beagles, M. Burstow, S.R. Lewis. Wear. 430-431, 383 (2019). Crossref

10. J. Kalousek, D. M. Fegredo, E.E. Laufer. Wear. 105, 199 (1985). Crossref

11. R. Skrypnyk, M. Ekh, J. C. O. Nielsen, B. A. Pålsson. Wear. 428-429, 302 (2019). Crossref

12. D. Kim, L. Quagliato, D. Park, N. Kim. Wear. 420 -421, 184 (2019). Crossref

13. Y. B. Huang, L.B. Shi, X. J. Zhao, Z. B. Cai, Q.Y. Liu, W. J. Wang. Wear. 400-401, 62 (2018). Crossref

14. O.A. Peregudov, K.V. Morozov, V.E. Gromov, A. M. Glezer, Yu. F. Ivanov. Russ. Metall. 4, 371 (2016). Crossref

15. V.E. Kormyshev, V.E. Gromov, Yu. F. Ivanov, A. M. Glezer, A. A. Yuriev, A. P. Semin, R. V. Sundeev. Materials Letters. 268, 127499 (2020). Crossref

16. V.E. Kormyshev, E. V. Polevoy, A. A. Yuriev, V.E. Gromov, Yu. F. Ivanov. Izvestiya. Ferrous Metallurgy. 63 (2), 108 (2020). (in Russian) [B.Е Кормышев., Е.В. Полевой, А.А. Юрьев, В.Е. Громов, Ю.Ф. Иванов. Известия Высших Учебных Заведений. Черная Металлургия. 63 (2), 108 (2020).] Crossref

17. V.E. Gromov, Yu. F. Ivanov, V. E. Kormyshev, A. A. Yuriev, A.P. Semin, Yu. A. Rubannikova. Progress in Physics of Metals. 21 (4), 527 (2020). Crossref

18. A. M. Glezer. Bulletin of the Russian Academy of Sciences: Physics. 71 (12), 1722 (2007). Crossref

19. A. Mazilkin, B. Straumal, A. Kilmametov, P. Straumal, B. Baretzky. Materials Transactions. 60, 1489 (2019). Crossref

20. V.E. Panin, I. A. Shulepov, L. S. Derevyagina, S. V. Panin, A. I. Gordienko, I. V. Vlasov. Physical Mesomechanics. 22 (6), 5 (2019). (in Russian) [В.Е. Панин, И. А. Шулепов, Л.С. Деревягина, С.В. Панин, А.И. Гордиенко, И.В. Власов. Fizicheskaya Mezomekhanika. 22 (6), 5 (2019).] Crossref 